\title{
A34＼cjkstart開張率と開張角の信頼性と開張足の診断基準值と障害予防の検討
}

\section{Reliability of Prevention of Disability and Diagnostic Index of Spread Flatness and Spresd Angle for Spread Foot}

$$
\begin{aligned}
& \text { ○正 清水 新悟（名古屋大） 正 長井 力（名古屋大） } \\
& \text { 正 元田 英一 (名古屋大) 正 大日方 五郎 (名古屋大) }
\end{aligned}
$$

Shingo SHIMIZU, Nagoya University, Furo-cho, Chikusa-ku, Aichi

Chikara NAGAI, Nagoya University, Furo-cho, Chikusa-ku, Aichi

Eiicti GENDA, Nagoya University, Furo-cho, Chikusa-ku, Aichi

Goro OBINATA, Nagoya University, Furo-cho, Chikusa-ku, Aichi

\begin{abstract}
It proposed the index value of the open Cho rate and the open Cho angle where the spread foot is simply judged without using $\mathrm{X}$ rays, and the relation to other diseases is investigated. As a result on subjects, $37 \%$ or more in open, 15 degrees or more reached the index value, and the pain by hallux valgus and the pain of the second metatarsal bone were often the cases in open. It seems to be necessary that some treatment with in-sole are required at the early stage to prevent from the injury if the decrease of horizontal arch is found.
\end{abstract}

Key Words : Spread Foot, Spread Flatness, Spresd Angle, Diagnostic Index, Prevention of Disability

\section{1. はじめに}

人間の足には片足 26 個の骨があり，第 2 中足骨は 中足骨の中で最も長く，負担が得られやすいといわれ ており, 疲労性の疼痛や骨折を起こしやすく, スポー ツ時に障害が出現する 1)。またスポーツ動作の走行時 やジャンプ動作にて第 3 趾や第 4 趾がしびれるモート ン病などもある ${ }^{2)}$. 以上の疾患は横アーチの低下から 起こる開張足によるものと言われており, 治療として は足底挿板などで横アーチの低下を防ぐ方法が多数報 告されている. しかし現在, 開張足の診断にはX線を 必要とするため, 事前に診断することは難しい状況に ある。そこで我々は障害を事前に防ぐために簡易的に 開張足を診断できる方法を提案する。.また，その信頼 性と開張足であると予測できる限界を明らかにし，他 の疾患（扁平足，外反母趾，内反小趾）との合併率や 疼痛箇所, 歩行耐久性の影響を調查したので報告する.

\section{2. 対象}

2008.1.7 2010.12.30までに著者の一人が所属する 病院にて開張足と診断された男性 9 例 14 足, 女性 27 例 48 足の計 36 例 62 足（右 4 例，左 6 例，両側 26 例）を調查対象とする. 対象は, 平均年齢が $49.1 \pm 19.5$ 歳, 平均身長が $158.0 \pm 9.5 \mathrm{~cm}$, 平均体重が $54.8 \pm$ $11.1 \mathrm{~kg}, \mathrm{X}$ 線での平均 M1-M5 角度（第 1 中足骨と第 5 中足骨とのなす角度）が $33.8 \pm 5.2^{\circ}$ となった。また全 例がボールを蹴る足は右である。

\section{3. 方法}

トレースの採取肢位は, 左右の上前腸骨稜を結んだ 線と踵から第 2 趾の線が直角となる方向を進行方向と して足を向け, 足踏みを 10 回行い，静止した時の足幅 を設定する.設定した足幅を保ちながら進行方向に向
けた足を身長の $45 \%$ 一歩前に出し, 出していない後方 の足を計測する.このとき後方足の足関節背屈角度は

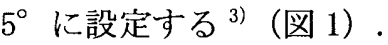

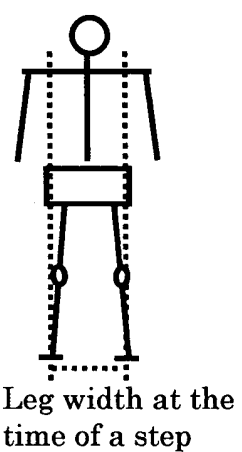

(a)frontal plane

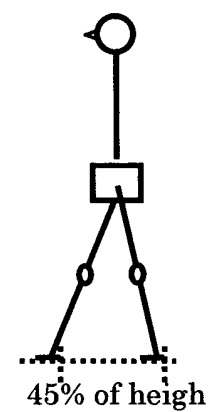

(b) sagittal plane

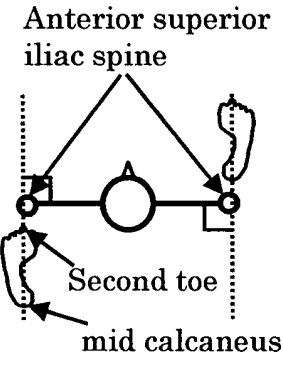

(c)horizontaltal plane
Fig.1 Measurement trace

トレースでの開張足の計測は, 永山らの第 1 中足骨 頭と第 5 中足骨頭を結ぶ線である足幅を実足長で除し た值である開張率を計測した ${ }^{4}$ （図 2）。また骨指標で ある第 1 中足骨頭と 内果後方を結ぶ線と第 5 中足骨頭 と外果後方を結ぶ線とのなす角度を開張角として計測 する ${ }^{5)}$ (図 3)。この開張率と開張角をX X 線での第 1 第 5 中足骨角（M1-M5 角 : 図 4) と比較し, X 線との相関性 をみる.また開張率と開張角を用いた時の開張足の評 価指標を算出する.計測は, 開張足の診断基準となる X 
線での M1-M5 角 $25^{\circ}$ 以上を考慮して $25: \mathrm{Y}=$ (開張角, 開張率）: X 線（M1-M5 角）となり，この式から Y の值を だして開張足の評価指標を算出して検討する.

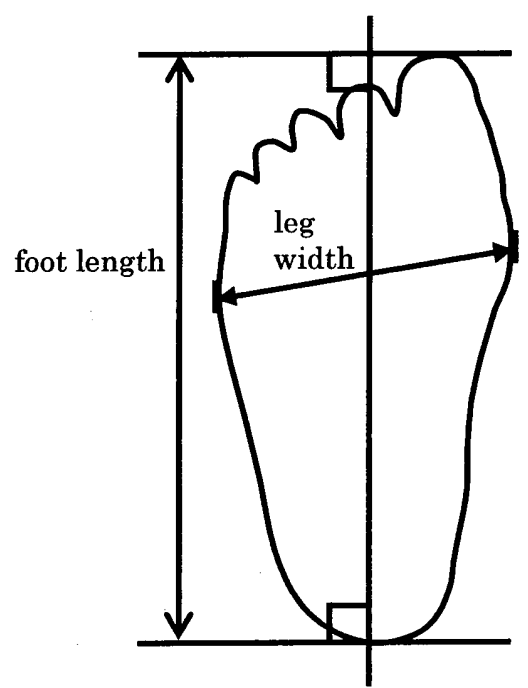

Fig.2 Spread Flatness=leg width/ foot length

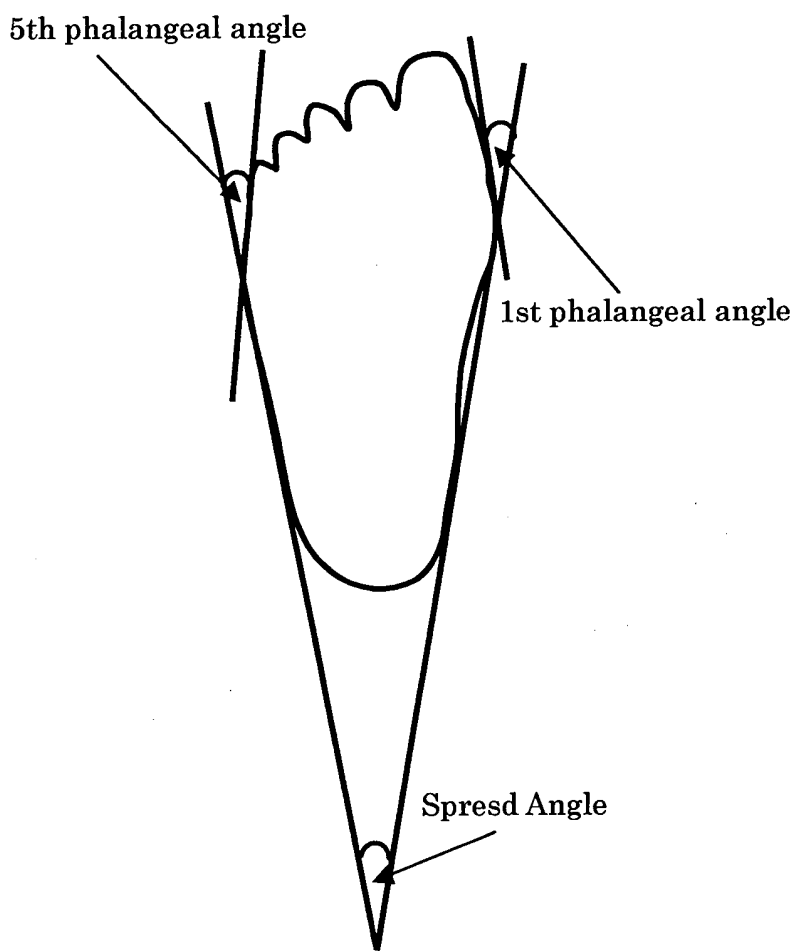

Fig.3 Spresd Angle and 1sh 5th phalangeal angle

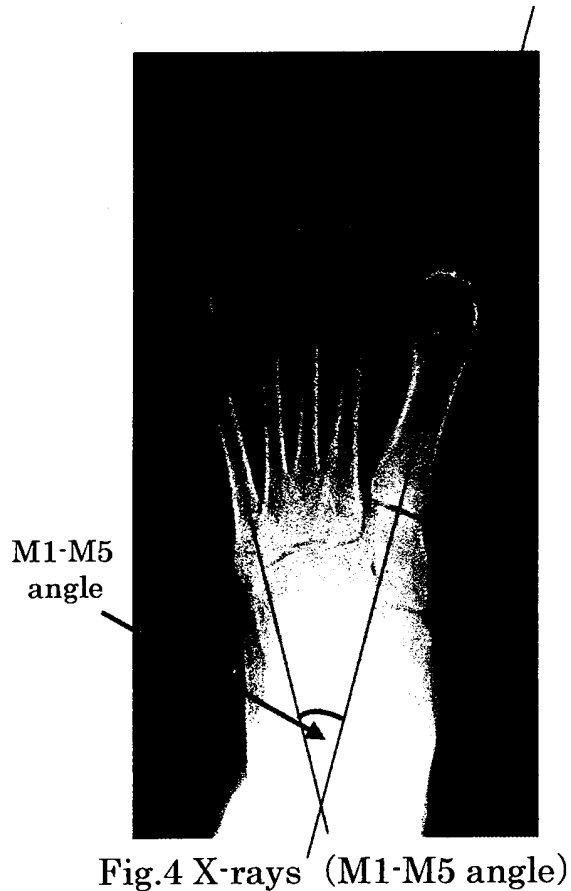

今回の開張足の症例において他の疾患との合併症を みるために内側縦ア一チ効率 (図 5), 第 1 趾側角度 (外 反母趾角度 : 図 3), 第 5 趾側角度（内反小趾角度 : 図 3）との相関性および扁平足，外反母趾，内反小趾の合 併率をみる ${ }^{6,7)}$. また足裏のタコ（胼胝）の位置を視診 にて確認し，疼痛䇢所を問診および触診にて確認する ことで開張足の胼胝の出現箇所や疼痛出現箇所を調べ る.さらに 6 分間歩行距離試験にて歩行時の耐久性を 確認するために M1-M5 角との相関性をみる. 6 分間歩 行距離は年龄などの影響を受けるため先行研究からの 基礎代謝で除した值にて相関性をみる ${ }^{8)}$.

統計学的分析はwinstat を用いて spearmanの順位相 関係数を用いた.

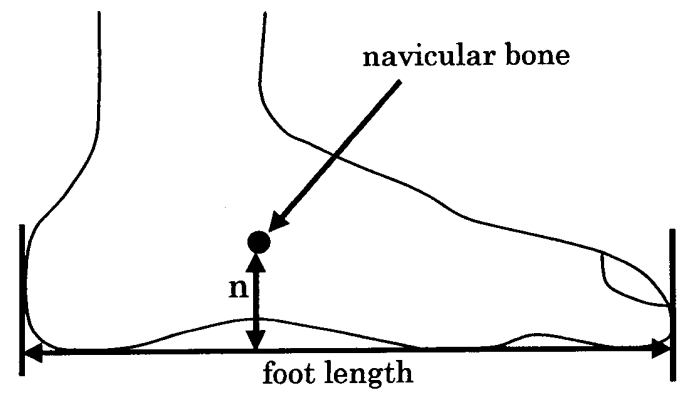

Medial longitudinal arch ratio $=\mathbf{n} /$ foot length

Fig.5 Medial longitudinal arch ratio 
4. 結果

4-1.X 線 M1-M5 角との相関性と基準値

右開張率は $\mathrm{r}=0.64594 （ \mathrm{p}<0.0005)$, 左開張率は $\mathrm{r}$ $=0.466276(\mathrm{p}<0.00094)$, 左右での開張率は $\mathrm{r}=$ $0.535733(\mathrm{p}<0.0001)$ となった（図 6). 右開張角は $r$ $=0.750612(\mathrm{p}<0.0001)$, 左開張角は $\mathrm{r}=0.578354 （ \mathrm{p}$ $<0.00013)$, 左右での開張角は $\mathrm{r}=0.653131 （ \mathrm{p}<$ 0.0001）となった（図 7). 開張率より開張角の方が相 関性は高く, 左より右の方が開張率と開張角にて相関 性が高い結果となった。

トレースでの開張足評価指標は，25：Y=（開張角， 開張率) : X 線 (M1-M5 角) の計算式にて行い, 平均開張 率が $32.8 \pm 4.2 \%$ となった. したがって開張率による開 張足の平均值から標準偏差を足した值が $37 \%$ で, $37 \%$ 以上が開張率を使用した時の開張足の予測值とした。 開張角にて計算を行い, 平均開張角が $13.5 \pm 1.7^{\circ}$ とな った.したがって開張足の平均値から標準偏差を足し た值が $15.2^{\circ}$ で, 実用值を考慮して少数第 1 位を四捨 五入すると $15^{\circ}$ となり，この值から $15^{\circ}$ 以上を開張足 と予測する.

\section{4-2. 障害発生率と傾向}

アーチ高率にての扁平足は右が $25 / 30$ 足 (83.3\%), 左が $28 / 32$ 足 $(87.5 \%)$ ，両側で $53 / 62$ 足 (85.5\%) と なった。第 1 趾側角での外反母趾は右が $24 / 30$ 足 $(80 \%)$, 左が $27 / 32$ 足 (84.4\%)，両側で 51/62 (82.3\%) となった. 第 5 趾角の内反小趾は右が 18/30 足 $(60 \%)$, 左が 19/32 足 (59.4\%)，両側で 51/62（59.7\%）とな った。胼胝の出現箇所の多い箇所は右足が第 1 中足骨 14 箇所, 第 2 中足骨 14 箇所と最も多く, 次に第 3 中 足骨 13 筒所であった（表 1). 左足が第 2 中足骨 13 箇所と最も多く, 次に第 1 中足骨 11 箇所, 第 3 中足 骨 10 箇所であった（表 1 ）。疼痛の出現箇所の多い箇 所は右足が第 1 中足骨 12 箇所と最も多く，次に第 2 中足骨 6 箇所，踵 5 箇所であった（表 2)，左足が第 1 中足骨 15 箇所と最も多く, 次に第 2 中足骨 13 箇所, 踵 7 箇所であった（表 2).6 分間歩行距離との相関性 は両側を含む右足で $\mathrm{r}=-0.09833$, 左足で $\mathrm{r}=-0.02603$ と相関性は得られなかった。

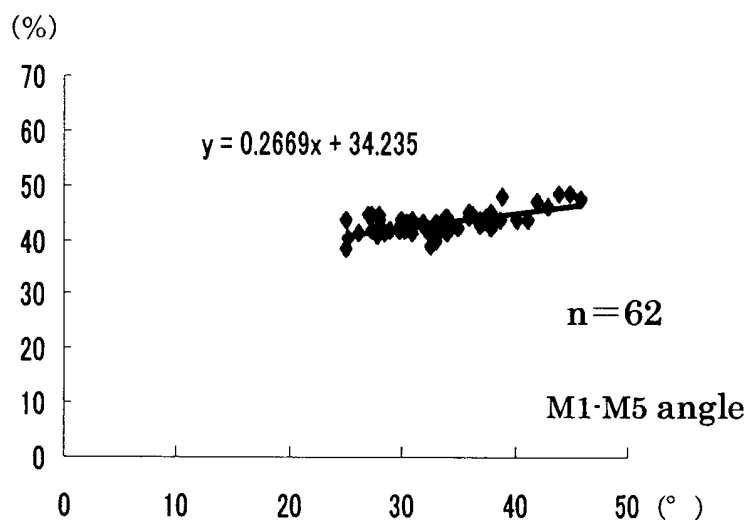

Fig. 6 Correlativity of x-rays (M1-M5 angle) and a spread flatness

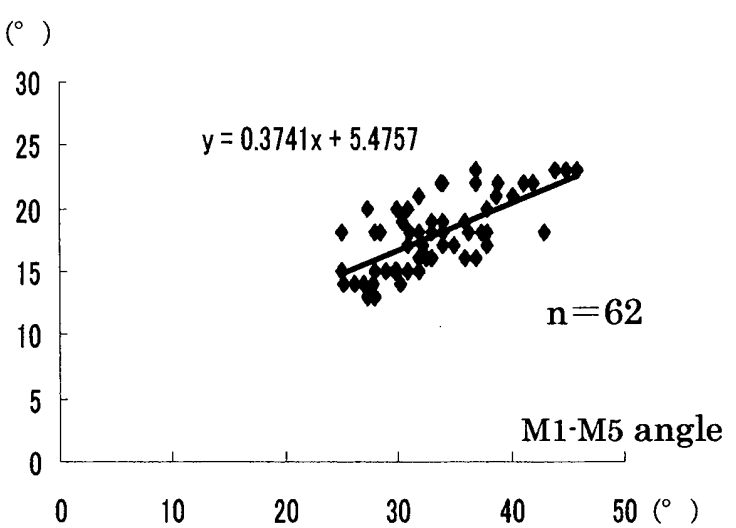

Fig.7 Correlativity of X-rays (M1-M5 angle) and a Spresd Angle

Table 1 The appearance part of a callus (those with duplication)

\begin{tabular}{lcc} 
& right & left \\
\hline The 1st metatarsal & 14 & 11 \\
The 2nd metatarsal & 14 & 13 \\
The 3rd metatarsal & 13 & 10 \\
The 4th metatarsal & 5 & 3 \\
The 5th metatarsal & 2 & 4 \\
calcaneus & 5 & 10 \\
\hline
\end{tabular}

Table 2 The appearance part of sharp pain (those with duplication)

\begin{tabular}{lcr} 
& right & left \\
\hline The 1st metatarsal & 12 & 15 \\
The 2nd metatarsal & 6 & 13 \\
The 3rd metatarsal & 3 & 4 \\
The 4th metatarsal & 3 & 1 \\
The 5th metatarsal & 1 & 0 \\
calcaneus & 5 & 7 \\
medial arch & 3 & 3 \\
navicular bone & 1 & 1 \\
\hline
\end{tabular}




\section{5. 考察}

5-1.X 線 M1-M5 角との相関性についての検討

開張率と比べ，開張角の方が X 線 M1-M5 角との相関 係数が高い. また左足よりも右足の方が相関係数は高 いことから開張角の右足が最も信頼性が高く, 対象は 右足が良い。しかしスポーツ選手のメディカルチェッ クなどの臨床においては，開張角はトレース用紙から 大きくはみ出るために画像上にての角度計測が必要で あり，開張率と比べ時間が掛かる。したがって臨床で は最も簡易的に計測が出来る開張率が良いかと思われ た. 両側での相関係数は開張率が $\mathrm{r}=0.535733(\mathrm{p}<$ $0.0001)$ ，開張角が $\mathrm{r}=0.653131 （ \mathrm{p}<0.0001 ） て ゙ あ り ，$ どちらも相関性が高く, 臨床にて使用できる. 基準値 の計算にて平均値に標準偏差を足した理由は, 高い数 值の方が開張足の可能性が高くなると思われたからで ある. 計算にて開張率が $37 \%$ 以上, 開張角が $15^{\circ}$ 以上 となり，この值よりも大きい場合は開張足の可能性が 高く，臨床ではドクターへの助言などに用いることが 可能である. またスポーツ選手などのメディカルチェ ックなどにも使用できる.さらに研究においても正常 足を選ぶときや開張足を選ぶときなどにも使用可能で あると考えられる。

\section{5-2.障害発生率と傾向についての検討}

開張足の合併症には，内側縦ア一千高率にて扁平足 が $85.5 \%$, 第 1 趾側角度にて外反母趾が $82.3 \%$, 第 5 趾 側角度にて内反小趾が $59.7 \%$ と高く, 横アーチの低下 は, 縦ア一チの低下, 母趾の変形, 小趾の変形と何ら かの関係があると思われる ${ }^{9)}$. しかし横ア一チの低下 により合併したのかは分からないが縌アーチの低下は 横アーチの低下を引き起こすという先行研究や縦ア一 チの低下は外反母趾との関係が無いという先行研究, 横アーチの低下により外反母趾や内反小趾が出現する という先行研究もあることから, 我々は繸ア一チの低 下から横アーチの低下が出現し，横アーチの低下から 外反母趾や内反小趾が出現したと推察した ${ }^{10-13)}$. 胼胝 や疼痛にても母趾が多数であり，外反母趾による影響 と思われる.内反小趾が約 $60 \%$ も居るのにもかかわら ず，胼胝や疼痛が第 5 中足骨頭に少ないのは立位時や 歩行時に第 5 中足骨頭に掛かる圧力が少なく，横ア一 チ低下による影響を受けにくいことが原因と推察され る. 第 2 中足骨頭に胼胝や疼痛が多数なのは, 第 2 中 足骨が最も長く, 動きが少ないと先行研究より述べら れていることから第 2 中足骨頭は歩行時に圧力が掛か りやすい力学的な構造をしており, 横ア一チ低下によ る影響を受けやすいと考えられる ${ }^{1)} .6$ 分間歩行距離は, $\mathrm{X}$ 線 M1-M5 との相関係数は小さいことから M1-M5 角度 との関係は無いと思われる. 疼痛と 6 分間歩行距離の
関係については，今回は調べていないため，今後の課 題として明らかにしていく必要がある.

\section{5-3.臨床においての障害予防についての検討}

横ア一チ低下による開張足に対しての障害は様々で あり, 特に外反母趾による疼痛と第 2 中足骨の疼痛が 多く，横アーチ低下を簡易的に評価して早期に予防す ることの意義が示唆された．予防としては横ア一チを 支持するためにアーチパッドなどの足底挿板が即時効 果を得るうえでは最も良いと我々は考えている.

本研究を行うにあたり，著者の一人が所属する病院 （あさひ病院）での理事会にて倫理審查のうえで許可 を得ており，また調査対象者に口頭ならび紙面上にて 十分な説明を行い, 同意を得ている.

\section{参考文献}

1）井口傑, 足のクリニック, 南江堂, 119-120, 159, 2005

2) 中川種史, モートン神経腫, 臨床スポーツ医学, Vo19 (増刊号)，245-248，1992

3）永山理恵, 横尾浩, 内田俊彦ほか : 開張足の判定に関 する検討ーフットプリントおよび足計測からー, 靴の 医学, $20: 64-68,2006$

4）清水新悟, 加藤幸久: 扁平足に対するフットプリン トとアーチ高率値の信頼性. 日本臨

床バイオメカニクス学会誌 , 30:243-248,2009

5）清水新悟, 加藤幸久, 前田健博ほか : フットプリント 上での外反母趾角と内反小趾角の評価検討. 日本足 の外科学会誌, 31:35-38, 113,2010

6）田中 康仁, 荷重時における前足の X 線学的変化に ついて, 日足外, 11, 91-97, 1990

7）奥田龍三: 内反小趾. MB Orthop, 12 (6) : 50-56, 1999 8）大塚博保，運動適性を考えるための基礎知識，高齢 者運転適性ハンドブック，53-60，2005

9）松本直子, 西尾功, 楠見浩行ほか: 第 1 趾側角と足 部の形態的特徵との関係について, 靴の医 学, 14, 8-11, 2000

10）山本晴康, 古屋光太郎, 宗田大ほか, 扁平足と外反 母趾の関係について, 日足外, 10, 86-90, 1989

11）田中康仁, 高倉義典, 杉本和也ほか, 外反母趾と扁 平足の関係について, 日足外, 12, 16-19, 1991

12）内田俊彦, 入谷誠, 黒木良克ほ加: 扁平足障害. 関 節外科, $13: 96-105,1994$

13）羽島正仁, 斉藤伸, 国分正一ほか: 扁平足. 関節外 科, 16 (6) : $79-85,1997$ 